\title{
Incidental Finding of Bilateral Dens Invaginatus in the Maxillary Lateral Incisors and Role of Cone Beam Computed Tomography in Diagnose and Treatment Rastlantısal Bir Bulgu Olarak Maksiller Lateral Dišlerde Dens
Invajinatus, Tanı ve Tedavide Konik Išılı Bilgisayarlı
Tomografinin Rolü
}

Emre Köse $^{1}$, Duygu Göller Bulut ${ }^{2}$, Özge Ulusan ${ }^{3}$

${ }^{1}$ Adnan Menderes University Faculty of Dentistry, Department of Oral and Maxillofacial Radiology, Aydın, Turkey

${ }^{2}$ Sivas Oral and Dental Health Center, Clinic of Oral and Maxillofacial Radiology, Sivas, Turkey

${ }^{3}$ Erciyes University Faculty of Dentistry, Department of Oral Endodontics, Kayseri, Turkey

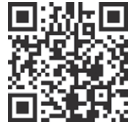

Keywords

Dens invaginatus, endodontic treatment, maxillary lateral incisors, periapical lesion, cone beam computed tomography

Anahtar Kelimeler

Dens invajinatus, endodontik tedavi, maksiller lateral kesiciler, periapikal lezyon, konik ışınlı bilgisayarlı tomografi

Received/Geliş Tarihi : 25.09.2016 Accepted/Kabul Tarihi : 20.11.2016

doi:10.4274/meandros.3004

Address for Correspondence/Yazışma Adresi: Emre Köse MD,

Adnan Menderes University Faculty of Dentistry, Department of Oral and Maxillofacial Radiology, Aydın, Turkey

Phone : +90 2562133939

E-mail : mail_emrekose@hotmail.com

(C) Meandros Medical and Dental Journal, Published by Galenos Publishing House.

This is article distributed under the terms of the

Creative Commons Attribution NonCommercial 4.0

International Licence (CC BY-NC 4.0).

\section{Abstract}

Dens invaginatus (DI) is a dental malformation commonly thought to occur as a result of an infolding of the enamel organ into the adjacent dental papilla during the development of the tooth. It shows a wide spectrum of variations in morphology and usually affects the maxillary lateral incisors. This study presents type $1 \mathrm{DI}$ involving bilateral maxillary lateral incisors, which presented as an incidental radiographic finding in the laterals and was associated with a periapical lesion in the right one without caries. The case was successfully treated using nonsurgical endodontic treatment.

Öz

Dens invajinatus (Di), mine organının diş gelişimi sırasında bitişiğindeki dental papillaya doğru katlanması sonucu oluştuğu düşünülen bir dental malformasyondur. Morfolojik olarak geniş bir varyasyon yelpazesi gösterir ve sıklıkla maksiller lateral dişleri etkiler. Bu çalışmada, rastlantısal radyolojik bulgu olarak tip 1 Di tespit edilen maksiller lateral dişler ve periapikal lezyonu olan çürüksüz sağ maksiller lateral diş ve bu dişin cerrahi olmayan endodontik tedavisi anlatılmaktadır.

\section{Introduction}

Dens invaginatus (DI) is a developmental anomaly characterized by an infolding of enamel and dentine. In 1856, a dentist named 'Socrates' first described DI in a human tooth. The etiology of DI malformation remains unclear and debated (1). Focal failure of internal enamel epithelium development, aggressive and rapid proliferation of a portion of the internal enamel epithelium occupying the dental papilla, external forces affecting the tooth germ during 
growth and also, genetic factors have been suggested to be the cause. It is more commonly seen in males, and maxillary permanent teeth with a prevalence of $0.04-10 \%$. DI is most commonly seen in permanent maxillary lateral incisors followed by central incisors, premolars, canines and molars $(1,2)$.

While the morphology of the lingual surface of the tooth might suggest a groove or fissure which may extend deep into the pulp cavity and into the root and sometimes even reach the root apex $(2,3)$. Numerous classifications have been done and Hallett (4) suggested the existence of four types of invaginations: Type 1: a definite cleft is found in the palatal enamel at the cervical level; the cleft runs vertically and there is no expansion or dilatation. Type 2: the invagination extends towards the pulp chamber and a definite pit is formed in the cingulum. Type 3: the invagination extends deeply into the pulp chamber and is dilated. Type 4: the invagination occludes the coronal pulp chamber and may extend beyond the cementoenamel junction level (5). Treatment of teeth with DI varies from preventive treatment to extraction according to the type of DI and periapical condition.

The diagnosis of $\mathrm{DI}$ is made based on radiographic evidence (3). The limitations related with the conventional radiography in the classification and therapy of DI can be overcome in the future with the growing availability of computerized threedimensional imaging (6). In this paper, a case of periapical lesion related with type $1 \mathrm{DI}$ was presented and the role of imaging method was discussed.

\section{Case Report}

A 17-year-old female complaining of pain in the right maxillary molar region was referred to an oral and maxillofacial radiology clinic. Her medical history was unremarkable. Panoramic radiograph showed impacted right maxillary first molar tooth root, well-defined cystic lucent lesion between the right mandibular molar teeth, maxillary lateral incisors with $\mathrm{DI}$, and periapical lesion related with right maxillary lateral incisor (Figure 1). During clinical examination, the right maxillary lateral incisor was asymptomatic (insensitive to percussion, without caries, fistula and color changes). Except right maxillary lateral incisor, other maxillary incisors were responsive to thermal and pulp vitality tests. Crown morphology of all the maxillary incisors was normal without any depression area on clinical examination. Before surgical procedure for the excision of the mandibular cyst, cone beam computed tomography (CBCT) was taken. During CBCT examination, bilateral $\mathrm{DI}$ in the maxillary lateral teeth and a periapical lesion measuring $5 \mathrm{~mm}$ in diameter were detected (Figure 2). Type 1 DI was located

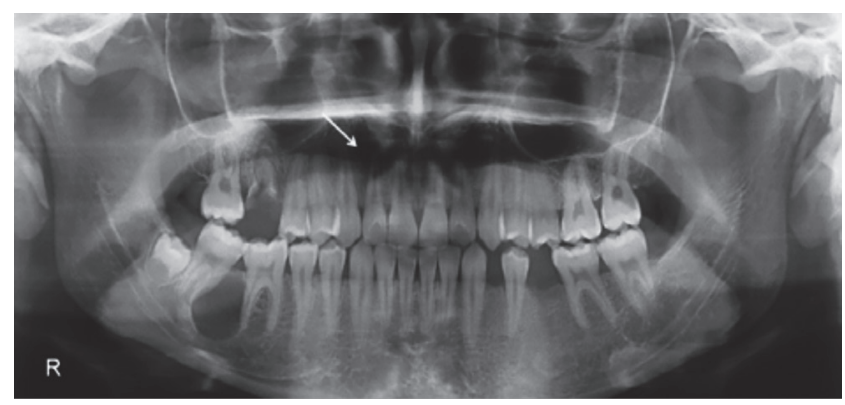

Figure 1. Panoramic radiograph (arrow shows periapical lesion)

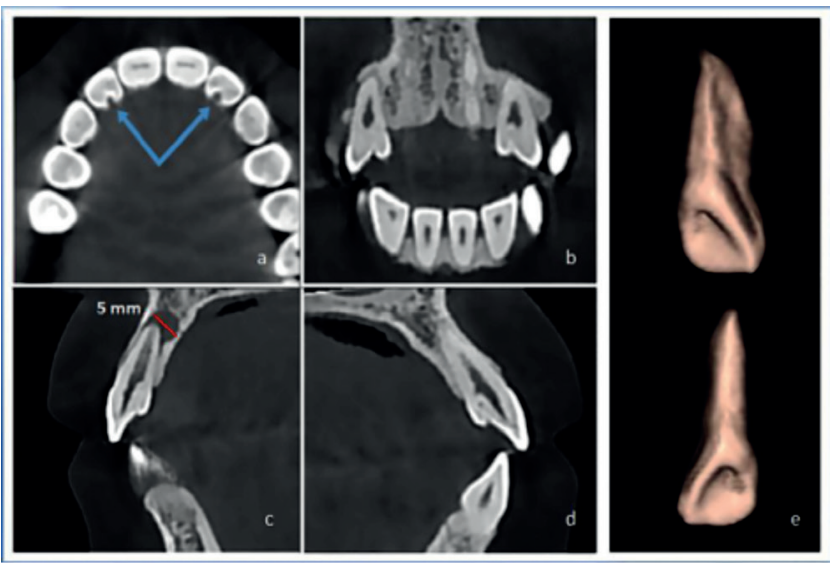

Figure 2. Cone beam computed tomography sections (a, b, c, d) (blue arrows show invagination, red line shows diameter of lesion), e) 3D images of maxillary lateral teeth

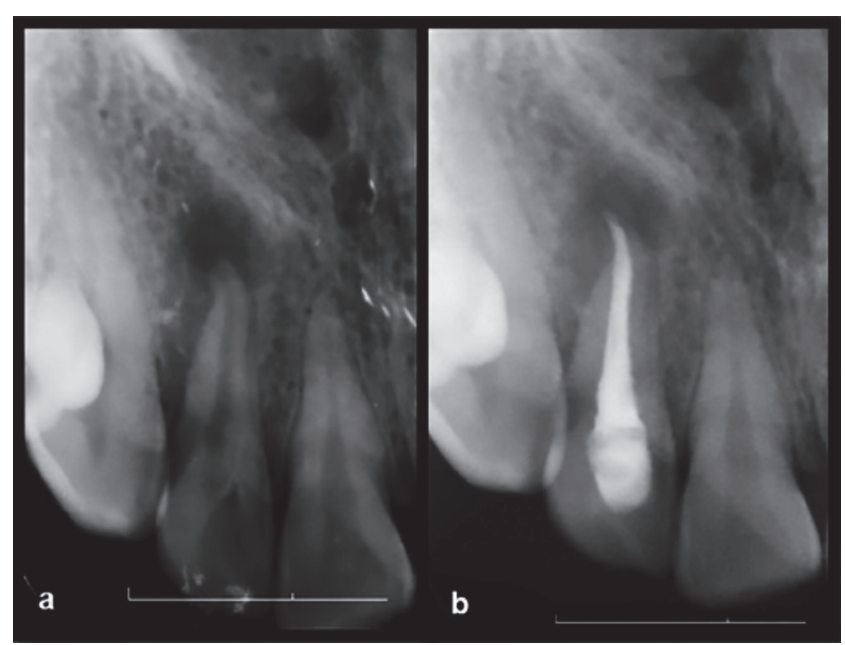

Figure 3. Periapical radiographs of right maxillary lateral tooth before (a) and after (b) endodontic treatment 
in the upper side of the cementoenamel junction. Non-surgical endodontic treatment was carried out over two visits under local anesthesia (Figure 3). The patient was recalled one month later and was found to be asymptomatic.

\section{Discussion}

Conventional radiographs give information that allows the clinician to build up a mental threedimensional image of the area of interest. The accuracy of this image is dependent on several factors, including the diagnostic quality of the radiographs and the clinician's skill, knowledge and experience interpreting these 2-dimensional images of the often complex dento-alveolar anatomy. On panoramic radiographs, palatoglossal air space lucency, magnification and distortion could prevent exact diagnose $(7,8)$. CBCT has been shown to be particularly useful in assessing the dimension of invagination, configuration root canal and periapical lesions of teeth presenting with endodontic problems.

In most cases, a DI is detected coincidentally on the radiograph. Clinically, an unusual crown morphology, such as barrel-shaped, peg-shaped, and dilated or a deep foramen caecum may be significant indications, but the affected teeth also may not show any clinical signs of the abnormality. After teeth eruption, coronal invaginations and pulpal involvement of the teeth may take place in a short time, thus, an early diagnosis is obligatory to make preventive treatment. The treatment alternatives are protective sealing of the invagination area, endodontic treatment, intentional replantation, periapical surgery, and extraction $(6,7)$. In our case, endodontic root treatment was done to the right maxillary lateral incisor. Since no depression area was present on the maxillary left lateral incisor, preventive treatment such as protective sealing was not required.

Several papers have reported that when the invagination has no communication with the main root canal, the pulp in the main canal remained healthy with successful non-surgical endodontic treatment of the necrotic invaginated area (9). Nonetheless, just two of these studies used CBCT for diagnosis and follow-up. Currently, advanced radiographic techniques with $\mathrm{CBCT}$ imaging may aid the diagnosis as well as the management plan and follow-up of teeth with this dental developmental anomaly $(8,9)$.
In this report, we presented a case of Hallet's type $1 \mathrm{DI}$ associated with a periapical lesion, and devital pulp. The main root canal was expected to contain unhealthy pulp, and CBCT evaluation revealed a connection between the main root canal and the invagination.

\section{Ethics}

Informed Consent: Consent form was filled out by all participants.

Peer-review: Externally and internally peerreviewed.

\section{Authorship Contributions}

Surgical and Medical Practices: Ö.U., E.K., Concept: E.K., D.G.B., Design: E.K., D.G.B., Data Collection or Processing: D.G.B., E.K., Analysis or Interpretation: E.K., D.G.B., Literature Search: D.G.B., E.K., Writing: E.K., D.G.B.

Conflict of Interest: No conflict of interest was declared by the authors.

Financial Disclosure: The authors declared that this study received no financial support.

\section{References}

1. Heydari A, Rahmani M. Treatment of dens invagination in a maxillary lateral incisor: a case report. Iran Endod J 2015; 10 : 207-9.

2. Mupparapu M, Singer SR, Goodchild JH. Dens evaginatus and dens invaginatus in a maxillary lateral incisor: report of a rare occurrence and review of literature. Aust Dent J 2004; 49: 201-3.

3. Hülsmann M. Dens invaginatus: aetiology, classification, prevalence, diagnosis, and treatment considerations. Int Endod J 1997; 30: 79-90.

4. Hallett GE. The incidence, nature, and clinical significance of palatal invaginations in the maxillary incisor teeth. Proc R Soc Med 1953; 46: 491-9.

5. Jimenez-Rubio A, Segura JJ, Jimenez-Planas A, Llamas R. Multiple dens invaginatus affecting maxillary lateral incisors and a supernumerary tooth. Endod Dent Traumatol 1997; 13: 196-8.

6. Thakur S, Thakur NS, Bramta M, Gupta M. Dens invagination: A review of literature and report of two cases. J Nat Sci Biol Med 2014; 5: 218-21.

7. Tagger M. Nonsurgical endodontic therapy of tooth invagination. Report of a case. Oral Surg Oral Med Oral Pathol 1977; 43: 124-9.

8. Patel S. The use of cone beam computed tomography in the conservative management of dens invaginatus: a case report. Int Endod J 2010; 43: 707-13.

9. Ceyhanli KT, Celik D, Altintas SH, Taşdemir T, S Sezgin O. Conservative treatment and follow-up of type III dens invaginatus using cone beam computed tomography. J Oral Sci 2014; 56: 307-10. 